\title{
Brexit and the Provision of Financial Services into the EU and into the UK
}

by

\author{
EDDY WYMEERSCH*
}

\begin{abstract}
Brexit is likely to lead to the relocation of $U K$ financial services firms to the $E U$ in order to be able to access $E U$ markets, mainly through the EU passport. The same applies to the EU firms intending to be active on the UK markets. The access conditions to the EU markets are numerous and complex, laid down in EU and national legislation and regulation, and applied by the national supervisory authorities. The European Supervisory Authorities or "ESAs" have published elaborate statements, called Opinions, on the detailed access conditions and the way they intend to apply these. The two main objectives are the full application of EU law, and the avoidance of authorizing EU firms that would be "empty boxes" for activity that would in fact be exercised in the UK, and this mainly by delegating activities to another firm. Underlying is a policy of competition between national economies for relocations of $E U$ firms, or of business activities to be developed on the UK financial markets.
\end{abstract}

Table of Contents

ECFR 2018, 732-771

A. Introduction . . . . . . . . . . . . . . . . . . 733

B. UK firms established in the EU . . . . . . . . . . . . . . . . . 733

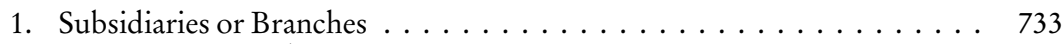

2. Access to EU markets . . . . . . . . . . . . . . . . . 735

3. Outsourcing and delegation in the applicable directives of regulation . . . 738

4. Positions of the regulatory and supervisory authorities as to the relocation of the UK firms to the European Union . . . . . . . . . . . 747

C. EU firms established in the UK . . . . . . . . . . . . . . . . . . . 763

1. Banking supervision: The Prudential Regulatory Authority PRA . . . . 763

2. Investment firms and market supervision: The Financial Consumer Authority . . . . . . . . . . . . . . . . . . 764

3. Statements about future supervisory practice $\ldots \ldots \ldots \ldots 766$

D. Conclusion . . . . . . . . . . . . . . . . . . . . . . . . . 769

* University of Gent, European Banking Institute. 


\section{A. Introduction}

The consequences of Brexit on the financial industry, both in the UK and in the EU, call for close attention not only from the financial institutions involved, but also from the financial authorities, and this both in the EU and in the UK. As the date for decisions by the financial institutions are approaching, the authorities have started to make public the way they intend to deal with the numerous requests for adaptations. Their positions are necessarily subject to the progress of the negotiations which have now been started and distinguish whether access to their respective markets will be granted or not. Different hypotheses are being analysed, going from full access - e.g. in case the UK joins the EEA - to access for a transitory period, or only for specific topics on the basis of Commission equivalence decisions, or finally in case no agreement is reached, leaving the UK without guaranteed access, and according to the residual position under the WTO, which however does not provide for financial services.

The following analysis will essentially be based on the applicable legal framework, and on the statements which have already been published by the respective supervisory authorities. During the run-up to the final date, the UK and the EU have adopted or announced statements about their action with respect to the changes in access to each other financial markets. From the UK side, this mainly concerns the so-called Withdrawal bill, still actively discussed in the UK Parliament, while several policy statements have been developed both by the UK authorities, and by the European institutions, especially also by the European Supervisory Authorities. This complex landscape will be analysed first as to the legal foundation on which these steps will be undertaking, secondly identifying in some detail their main characteristics, and finally to identify the differences in policy behind these initiatives.

\section{B. UK firms established in the EU}

\section{Subsidiaries or Branches}

From the European side the location of banks originating from the UK has been the subject of elaborate discussions and legal analysis. Many UK-domiciled banks, especially the ones with an investment bank profile, have been present for several years in the EU often by way of one or more fully owned subsidiaries. These entities are full EU credit institutions and could further be active as the EU arm of the UK or international banking group, allowing them to establish branches in other EU states or providing services in the EU (passporting). Often their range of products or services is focused on invest- 
ment banking, offered by way of provision of services. In the context of Brexit, many of the largest entities - especially the American groups - are already planning to activate their pre-existing subsidiaries or establish new ones providing a wider range of services. They will not have to apply for new authorisations, but due to changes in their business model or in the volume of activity, they will have to be screened by the EU competent authority ${ }^{1}$. This process for the authorisation or for its review is under way, involving the national supervisors and, where applicable, the ECB with respect to both large and small entities, applying the national and the EU wide requirements. There is no differentiation as to whether these applications originate from parent companies from the UK, or from any other non-EU jurisdiction, nor whether they were submitted before or after Brexit. Generally, the EU regulation will apply, standing for a largely uniform EU wide regime. National legislations may however impose additional conditions, or make access more difficult in practice. For non-EU applicants, banking regulation does not grant a right to access and the national regulations might be selective as to the origin of the firms they admit ${ }^{2}$. It should be remembered that applications for new authorisations in the euro area are processed at the national level, and - for banking ultimately approved by the ECB. For applications for establishment from the non-euro area jurisdictions, the national authorities will grant the authorisation according to the applicable EU regulations: for banking or investment firms, access will be granted essentially according to the national legislations adopted pursuant to CRD IV and MiFID II, to be supplemented by important regulations, such as the CRR or the MiFID regulation, or the SSM regulation for Significant Banks. An interesting general consideration is that when the UK will be qualified as a third country, "in practice the degree of economic and financial integration after Brexit will be significantly greater than with any other third country"'. This attitude explains the more cooperative attitude adopted in e.g. the EBA opinion.

Non-EU Credit institutions can also establish branches in the EU member states. Their regime will be governed by national legislation of the state of establishment, and their activity limited to that state. Offering services may be allowed, in some cases restricted by local regulations, e.g. for consumer or

1 See ECB, Relocating to the euro area. Procedure for the relocation of banks to the euro area in the context of Brexit (April 13, 2017), available at https://www.bankingsupervi sion.europa.eu/banking/relocating/html/index.en.html.

2 For EU firms, refusals have to be based on objective reasons based on the public interest, and restrictions have to be proportionate. These rules do not apply to third country firms applying for access.

3 EBA Op/2017/12, Opinion of the European Banking Authority on issues related to the departure of the United Kingdom from the European Union (October 12, 2017), p. 3. 
mortgage credit. Supervision will be national, or exercised by the ECB if part of a significant group.

With respect to investment firms, a similar regime applies. In some cases, financial groups - even banking groups - may stablish investment firms in the EU as separate legal entities. These subsidiaries enjoy the full EU regime as an investment firm and can offer their services all over the EU. In many cases this option is economically not feasible since too expensive. Therefore, investment firms often used the branch format, limited to the member state of their location. Under MiFID II, the option is still open but is limited: the firm has to be authorised and should meet the conditions mentioned in the regulation as verified by that member state's $\mathrm{NCA}^{4}$. There is no equivalence regime as such: the latter will be opened up under MiFID II once the Commission will have established an equivalence regime relating to the non-EU markets 5 . Passporting will be one of the important advantages. In exceptional conditions, such as in the case of "reverse solicitation", services may be delivered without establishment.

\section{Access to EU markets}

Within the general regulatory regime, access to EU markets in the context of Brexit will imply the application of the general provisions and conditions laid down in the EU regulatory regime, which contains some additional conditions for the first access from third country jurisdictions and will become applicable to UK firms applying for the continuation of their activity in the EU. If these firms are organised as subsidiaries and hence qualify as EU legal entities, there will be no need to apply for a new authorisation. However, additional or strengthened conditions will become applicable, as a consequence of the change to more local activity of the subsidiary; the increase of the volume of its operations, the mandatory adaptation of the organisational structure, conditions relating to the parent company, e.g. as a fit and proper shareholder etc. If new UK related entities will be set up, the entire authorisation procedure will apply. In many cases these new entities will be former branches being converted into subsidiaries in order to be able to enjoy the European passport, and further offer their services in several Union states. Their previous legal status will not play a significant role in the new authorisation procedure.

4 See Article 39 MiFID II; the conditions in Article 41 MiFID II; for "reverse solicitation" (or: "the provision of services at the exclusive initiative of the client"): Article 42 MiFID II.

5 See Article 46 et seq. MiFIR, allowing for activities "throughout the Union”. 
Whether previously existing branches will continue to be active without changes in their structure, or whether new branches will be created depends on the type of activity. These branches would be subject to the local rules and authorisations of the jurisdiction where they are located ${ }^{6}$. Therefore, being limited to the local market, location decisions will depend on the potential market: branches may expect sufficient business if located in the largest EU states.

The ESAs have published extensive memos (here referred to as "Opinions") dealing with the points which will be of special importance in the authorisation of these UK related entities. These will be analysed later?.

A second set of conditions for access to the EU markets will be the effectiveness of their location. Although this requirement is not new, it has been of central importance in the Brexit "relocation" debate.

Brexit has raised a debate about what is the real activity of a financial services firm, and hence where its real or economic location is situated. This debate was stirred by the concern that a number of UK financial services firms might establish operations in the EU which cover only part of the full activity of similar firms in that sector. The question concerns financial services firms not only from the UK, but from all third country jurisdictions, and existed before the UK leaving the EU. This practice refers to an organisation in which the EU part of the activity mainly relates to the internal administrative and client facing activity, including the registration of clients' transactions and related operations. The real financial activity, or the transactional aspect, such as the lending business or the asset management strategy and related activity like the portfolio selection and risk strategy, is then located in another country, often at the parent company's headquarters. From there, the assets could be managed and transactions processed, often as part of the wider activities of the group. The substance of the EU part of these firms in terms or regulation and supervision could be very thin, sometimes almost inexistent. As long as the other country was part of the Union, freedom of services, identical regulatory basis and cooperation between supervisory authorities were mostly considered sufficient to deal with the potential risks of this firm structure. These principles are not applicable to relations with third countries: hence the fundamental scheme lost its regulatory justification.

In the Brexit context, this scheme comes under pressure: the former UK firms will become third country firms, triggering a certain number of additional requirements dealing with equivalence and supervisory cooperation. This

6 See for Investment firms, the conditions imposed by Article 39 et seq. MiFID II.

7 See further sub 4. 
question became especially preoccupying as it might have resulted in the UK firm being considered to be in the EU, while the UK - and the related business activity - has left the Union. From a supervisory point of view, and unless specific conditions of cooperation can be worked out, this pattern cannot further be considered acceptable.

This explains why the three European supervisory authorities and the ECB have stated their formal position on the subject and indicated some of the criteria to be respected as a "genuine" EU establishment of a third country firm $^{8}$. These opinions have developed their point of view under the heading of "delegation" or "outsourcing", being aware that these are the most frequently used ways of transferring the financial effects of transactions to another country, although by no means the only ones.

These Opinions contain a number of criteria or indications which supervisors should verify to assess whether the third country firm stays within the limits of a firm's essential activity within the EU. A cross reading of these Opinions points to several common aspects to which third country firms will have to pay attention to secure their initial or continuous access to the EU markets. The issues concern the entire range of financial services firms, active in all regulated financial activities: credit institutions, investment firms and markets, investment managers and investment funds, but also insurance enterprises, payments institutions etc.

8 EBA Op/2017/12, Opinion of the European Banking Authority on issues related to the departure of the United Kingdom from the European Union (October 12, 2017); ESMA Opinion 42-110-433, General principles to support supervisory convergence in the context of the United Kingdom withdrawing from the European Union (May 31, 2017); ESMA Press Release 71-99-469, ESMA Issues principles on supervisory approach to relocations from the UK (May 31, 2017); ESMA Opinion 70-154-270, Opinion to support supervisory convergence in the area of secondary markets in the context of the United Kingdom withdrawing from the European Union (July 13, 2017); ESMA Opinion 34-45-344, Opinion to support supervisory convergence in the area of investment management in the context of the United Kingdom withdrawing from the European Union (July 13, 2017); ESMA Opinion 35-43-762, Opinion to support supervisory convergence in the area of investment firms in the context of the United Kingdom withdrawing from the European Union (July 13, 2017). 


\section{Outsourcing and delegation in the applicable directives of regulation}

\section{a) Outsourcing v. Delegation}

In many other sectors of our economy, the practise has developed to contract out certain activities to third party service providers, often to entities part of the group, especially if the services can be provided at lower salaries. The financial sector is no exception in this respect. The administrative processing of transactions, including their accounting treatment by firms located e.g. in India has been successfully practised for many years. Outsourcing of other activities such as the location of transactions in another entity - a billing centre, where the invoices are produced - has been usual in many sectors of the industry. Outsourcing of IT services or call centres have been commonplace for big and small enterprises. Proof reading of legal manuscripts for UK editors is often executed in Asia, by experienced non-native proof readers.

Economies of scale, differences in remuneration, but also differences in applicable regulations and supervisory requirements may lie at the basis of this practice. In the EU regulations, these practices are usually referred to as "outsourcing" or as "delegation" of functions.

The different treatment of outsourcing from delegation reveals the nature of each of these: outsourcing mainly relates to technical acts, not involving much of decision making and hence presenting less risks for the financial institution. But risks may nevertheless emerge, e.g. a call centre giving wrong information. Delegation means essentially the transfer of decisional, judgmental matters and may therefore be source of considerable risk, justifying stricter regulation. The differences between outsourcing and delegation may become increasingly difficult to make: is a robot advisor, based on AI, to be classified under delegation, implying some judgmental call, even when all decisions are made without any human intervention? Some basic principles apply to both forms of organisation: the delegating party remains responsible for the outcomes and should oversee the way the activity is performed'. The regulation for delegation is generally stricter, providing for equivalent supervisory conditions, for supervisory cooperation, and defining the limits of activities which cannot be delegated.

9 Article 21 (3) AIFMD and Article 75 Delegated Regulation 231/ 2013; Art 30 CSDR on outsourcing; Article 31 and Article 47 MiFID II and the Delegated Regulation 2016/ 2398; Article 31, Delegated regulation 2017/565. 
b) Overview of delegation or outsourcing provisions in some directives and regulations

\section{(i) Outsourcing}

Outsourcing is mentioned in certain directives or regulations. From the supervisory angle, the core concerns are that the outsourcing entity should remain in full control and bear full responsibility while its supervisors should be able to fully access the outsourced activity and relating data, in some cases even running on-site inspections, or imposing fines. Outsourcing may create operational risks but should not create additional financial risks: it should not lead to delegation of responsibility. The rules relating to outsourcing are not different whether EU or non-EU firms are being addressed.

Article 190 of the CRR, dealing with "credit risk control", after having defined the core responsibilities of the risk control units, lists the activities that may validly be outsourced. These relate mainly to information collection and reporting, allowing to monitor and grade risk pools and rating criteria. Fees paid for outsourcing services to non-group entities will be accounted for under "operating expenses" for establishing the relevant calculator ${ }^{10}$. Article 65(3) CRD IV mentions that authorities could obtain information from outsources, to whom "operational functions or activities" have been outsourced.

MiFID II provides that outsourcing of important operational functions to third parties is subject to additional safeguards to avoid additional operational risk. Important or critical operational functions may not be outsourced if this would materially impair the quality of internal controls or the supervisor's ability to effectively supervise compliance with the firm's obligations. ${ }^{11}$

MiFID II especially refers to outsourcing to third parties - intra or extra EU but only refers to information obligations of the EU firm. It should not affect the firm's internal controls nor the supervisory activity of the authorities ${ }^{12}$.

CSDR contains several references to "outsourcing" of activities by CSDs, including to third country CSDs, what may not lead to delegation of responsibility and should not prevent the exercise of supervisory functions ${ }^{13}$.

Solvency II follows a broader definition for outsourcing as it may relate to "an arrangement of any form between an insurance or reinsurance undertaking and a service provider, (...), by which that service provider performs a process,

10 Article 315 CRR.

11 Article 16(5) MiFID II, as part of the organisational requirements for investment firms.

12 Article 40 MiFID II.

13 Article 30 CSDR; see also Article 19 CSDR. 
a service or an activity, whether directly or by sub-outsourcing, which would otherwise be performed by the insurance (...) undertaking itself" ${ }^{14}$. As in other provisions, supervisors should have effective access to data relating to the outsourced activity ${ }^{15}$. The outsourcing entity remains fully responsible ${ }^{16}$.

\section{(ii) Delegation}

The technique of delegation is known in several parts of the existing financial regulatory system ${ }^{17}$. It has attracted attention in the field of asset management including in the investment fund sector.

In the investment funds area, "delegation" as this is known in the applicable regulations has often been a subject of regulatory attention. While recognising the validity of the delegation, the 2009 UCITS Directive makes it clear that the management company may not delegate the totality of its functions to third parties and become a "letter-box" entity. The effectiveness of supervision should in any case remain guaranteed. Moreover, the delegating company will remain liable for the functions it has delegated ${ }^{18}$. The most critical form of delegation is that of investment management itself: here the directive allows Member States to provide for delegation to third entities if these entities are authorised or registered for asset management and subject to prudential supervision ${ }^{19}$. Moreover, the delegation must follow the investment allocation criteria adopted by the management company. It is allowed to delegate asset management to entities in third countries provided appropriate cooperation has been agreed upon between supervisors. Delegation may be considered an alternative formula to investment in a fund in another jurisdiction. In the investment fund field, some incidents have urged the EU regulator to introduce stricter rules for delegation of the custody or safekeeping function: delegation and sub-delegation are authorised - even to third country delegates - under some strict conditions ${ }^{20}$. The core provision here is that delega-

14 Article 11 (28) CSDR (defining outsourcing).

15 Article 38 Solvency II, dealing i.a. with the allocation of supervisory powers, even in the absence of an insurance supervisor.

16 Article 49 Solvency II, providing for additional safeguards in case of outsourcing of "critical or important functions".

17 Even for supervisory activities, the legislation knows some cases of delegation: E. Wymeersch, Delegation as an instrument for financial supervision, available at https://ssrn. com/abstract $=952952$.

18 Article 16 Directive 2009/65/EC referring to "letter box entities".

19 Article 13 Directive 2009/65/EC; some activities, esp. client facing activities may not be delegated: see Article 22 (a) Directive 2009/65/EC.

20 Certain functions cannot be delegated: see Article 22 (3) and (4). Among the conditions: Suitability of the third party, its due skill care and diligence, and assets should be duly 
tion will not change the liability of the original depository, which is held to strict liability: he remains held to restitute the securities or funds in any case, if these are lost by the depositary or by the delegate and whoever was responsible for the $\operatorname{loss}^{21}$.

The most elaborate regime of delegation is found in the AIFMD and the relating Commission delegated regulation ${ }^{22}$. The general principles for the delegation of AIFM functions ${ }^{23}$ require delegation to be based on objective reasons, and not as a technique to circumvent responsibility or liabilities. The financial supervisor will verify this point. In general delegation or sub-delegation does not put an end to the final responsibility to the AIFM, who always have to act in the best interest of the investors. The AIFM should at all times dispose of the necessary tools to ensure it is able to exercise full control of the delegated activities. His liability must be covered by adequate insurance ${ }^{24}$. Certain activities cannot be delegated, such as prime brokerage, or are subject to additional safeguards, such as portfolio and risk management ${ }^{25}$. Letter-box companies are mentioned in the directive, but more specific criteria are laid down in the regulation, dealing i.a. with requirements on expertise, resources, investment management beyond certain limits ${ }^{26}$. The Commission is in charge of monitoring the application of this regime on letter box entities and if the conditions are not fulfilled, this may lead to withdrawal of the authorisation of the AIFM with respect to managing $\mathrm{AIFs}^{27}$.

Preceding the similar rules under the UCITS directive, the AIFMD imposes specific safeguards relating to the depositary function. With respect to third country depositaries the directive provides in the same safeguards as provided

segregated; see Recital (20) of Directive 2014/91/EU. High levels of investor protection, rules on conduct and conflicts of interest should apply, especially by introducing a clear separation of tasks and function between the custodian, the UCITS and the management company, see Article 22 (a) (3) UCITS-Directive (as amended by Directive 2014/91/ EU). A special regime applies to delegation of the custody function relating to third country securities if no local entities satisfy the delegation criteria, Article 25 (a) (3) UCITS-Directive.

21 Article 22(a) and 24(a) UCITS-Directive (as amended by Directive 2014/91/EU); see also: Delegated Regulation(EU) 2016/438.

22 Directive 2011/61/EU; Delegated Regulation (EU) 231/2013. For an analysis, see Mason, Hayes \& Curran, Delegation of Investment Management under the AIFMD, available at https://www.mhc.ie/uploads/mhc_delegation_of_investment_management_under_the_aifmd.pdf.

23 Article 20 AIFMD.

24 See Article 15 Delegated Regulation (EU) 231/2013.

25 Article 80 Delegated Regulation (EU) 231/2013.

26 Article 82 (1) Delegated Regulation (EU) 231/2013.

27 Article 82 Delegated Regulation (EU) 231/2013. 
for clients of EU depositaries ${ }^{28}$. Delegation of the depository function to a third country institution is allowed under very strict conditions, largely identical to the ones applicable within the EU, such as prudential supervision ${ }^{29}$. The liability of the primary depositary is formulated as strict liability, and will apply, unless he can prove that the "loss was caused by an event beyond his reasonable control"30.

(iii) Regime of delegation to third country institutions according to the directives

This short overview has brought to light that the concerns about delegation and outsourcing have been alive for many years, but lead to an open approach within the EU, with the home supervisor being adequately armed to check the essential provisions to be respected.

Delegation, and to a lesser extent outsourcing may in extreme circumstances, lead to a full transfer of internal functions of a financial institution so that the remaining organisation would not allow that institution to function on its own, as a sole entity. The remaining entity may have become a "letter-box entity", without any significant or relevant decision-making power of itself, and would not exercise the essential functions of the type of firm it presented itself to the outside world. The phenomenon exists in several parts of the economic world, in different forms and intensities and has been considered acceptable if these presented added value, or economies of scale. But when the core business judgments are transferred, objections may be raised. Depending of the specific facts, the independent existence of the delegating firm may be denied, leading to attribute its activity to the delegator, and rendering the latter responsible in case of insolvency ${ }^{31}$. In the field of portfolio management, the effective portfolio management policy may be delegated to specialised man-

28 Article 21 (17) AIFMD: ,the Commission shall adopt implementing acts, stating that prudential regulation and supervision of a third country have the same effect as Union law and are effectively enforced".

29 Article 21 (11) AIFMD.

30 Article 21 (12) AIFMD (,the consequences of which would have been unavoidable despite all reasonable efforts to the contrary.”); compare the identical formulation in Article 24 (1) UCITS-Directive.

31 There might also be a breach of the obligation to have registered office and business office at the same place: Article 5 (4) MiFID II; Article 7 (1) (d) UCITSD; Article 8 (1) (e) AIFMD (a rule which can be analysed as an early instrument against abusive delocalization). These cases have been well documented both in the context of group law, and more exceptionally between independent companies; see European Company Law Experts (ECLE), A Proposal for Reforming Group Law in the European Union-Comparative Observations on the Way Forward, available at https://ssrn.com/abstract=2849865. 
agers, not necessarily known to the portfolio investors, and creating additional issues if several portfolios are managed on a common basis, generating risks in terms of price sensitive information or even conflicts of interest. These practises have been known for many years but do not seem to have raised significant supervisory concerns. The relevant directive contains detailed provisions allowing to limit the scope of the delegation and requiring delegation to be based on "objective reasons" 32 Also, the practice was not negatively addressed in the regulations on UCITS and on AIFM"33.

Although delegation and outsourcing have been widely practised in the financial sector, there seems to be a stricter attitude being developed by the regulators and supervisors to the extent that delegation and outsourcing may stand in the way of the exercise of their supervisory powers, limit their oversight of the remaining activities of the firms, and ultimately prevent to assess the risks that may flow from these practices, ultimately affecting the supervised firm.

Delegation often takes place within the EU: it may then be considered to benefit from the rules on freedom to provide services and should be considered valid. But delegation should be limited, and not impinge on activities that leave the existence of the delegating body intact. Delegation of all activities would raise questions about the real existence of that body, and to whom its acts have to be attributed. Whether delegation to third country entities should receive the same treatment is open to discussion.

The limits of delegation and outsourcing have recently received additional attention as a significant volume of delegation took place in favour of UK firms, due to their central position in the European financial markets. Before Brexit, delegation was part of the internal provision of services among EU firms, subject to the same level of supervision. After Brexit, the question arises under what conditions EU firms can receive financial services from non-EU firms, which in the absence of an equivalence regime, are not subject to the same safeguards. EU authorities would not have a statutory basis for requesting information, undertaking inspections, or even imposing fines to third country subcontractors which are outside the reach of the EU law. Regulators will be very loath to accept responsibility for activities which legally remain beyond their reach. In case of mismanagement of misbehaviour, they may have few excuses ${ }^{34}$. The contractual basis on which their actions would be under-

32 See Article 76 Delegated Regulation (EU) 231/2013.

33 Article 75 Delegated Regulation (EU) 231/2013 contains the general principles of delegation, with a special section dealing with portfolio management, essentially providing that the delegation is in line with the investment policy of the delegator.

34 See the regime of the depositary under the AIFMD and Articles 100-103 Delegated Regulation (EU) 231/2013. 
taken, would not resist a likely challenge in the non-EU jurisdictions $s^{35}$. In the absence of a regulatory basis for an equivalence assessment, after Brexit, it would seem that this type of activity would not further qualify as a permissible form of delegation.

In the field of portfolio management, the directive on UCITS and the MiFID II delegated regulation provide in an explicitly organised regime allowing EU investment firms to "outsource" to third country service providers "the investment service of portfolio management" under a certain number of conditions, including a cooperation agreement with the supervisory authority of the service provider ${ }^{36}$. There are no express conditions as to how far this form of delegation of portfolio services can validly be agreed.

Objections to delegation - and to comparable techniques - are often mentioned in the context of "excessive" delegation, i.e. that this practice may lead to "letter box entities", or to "empty shell companies" which would negate the separate existence of the delegator. Different techniques are mentioned. Contractual delegation is the most frequently used: when essential functions have been outsourced to another firm, what remains are essentially secondary, formal or passive functions. Comparable outcomes result from back-to-back invoicing, where transactions as agreed by a firm located in the EU are immediately offset by an identical transaction with the party located in another, possibly a third country ${ }^{37}$. The EU side might become a bookkeeping facility, an "accounting entity", without any financial consistency. A comparable outcome is achieved when an EU entity would act as an - independent or not - agent for the foreign entity. Depending on the contractual arrangements, the transaction would be attributed to the non-EU entity and hence would not be booked in the accounts of the latter. Similarly, if the agent did not hold a licence to operate in the EU, the activity might still be based on the "reverse solicitation" exemption, which is based on the idea that investors may always directly and voluntarily address themselves to third country intermediaries ${ }^{38}$. In this case, active canvassing is not allowed and is likely to be strictly applied by the supervisory bodies. But does it also cover further transactions flowing

35 Due to differences in standards of liability. In the Brexit case, execution of judicial decisions of UK jurisdictions in the EU would be problematic.

36 See Article 13 (1) (d) UCITS-Directive; Article 32 Delegated Regulation (EU) 2017/ 565.

37 See for an analysis EBA Op-2017-12, Opinion of the European Banking Authority on issues related to the departure of the United Kingdom from the European Union (12 October, 2017), p. 46 (no. 114); in fact, a comparable practice is followed for derivatives' clearing in the CCP, but a special regime applies there.

38 Article 42 MiFID II. 
from a pre-existing relationship ${ }^{39}$ ? The "reverse solicitation" regime is also different from state to state, leading to specificities and additional limitations or flexibilities ${ }^{40}$.

The arguments for refusing "letter box entities" to be active may be partly due to supervisory, partly to competitive concerns, and are applicable to both intra- and extra-EU delegation of fund management. Delegation to third country service providers may however create substantial supervisory risks to investors and creditors, as the latter may not be able to exercise effective recourse on the entity and its few remaining assets, while these often lightly capitalised firms will be liquidated before investors can act and disappear from the radar screen. As the cost structure will be different, one may also fear a competitive distortion with local firms, raising concern of unfair regulatory competition. In supervisory terms, these firms will not allow the full supervisory regime to be applied: their actions and policies will be dictated by outside instructions, assets will be held abroad, risk controls may be difficult

39 See Shearman and Sterling, proposing a very wide allowance for "reverse solicitation", Continuity of contracts and business on a hard Brexit: Human rights and reverse solicitation to the Rescue! (October 31, 2017), available at https://www.shearman.com/ perspectives/2017/10/continuity-contracts-business-on-hard-brexit. IRSG, The EU's third country regimes and alternatives to passporting (January 23, 2017), available at: https://www.irsg.co.uk/assets/IRSG-Full-report-The-EUs-third-country-regimesand-alternatives-to-passporting.pdf, has doubts about the technique considering whether this exception would allow active canvassing (see p. 15 and p. 118). See further on this issue, raised also in the context of continuity of contracts: ISDA, Response of ISDA to the European Commission Consultation Document on conflict of laws rules for third party effects of transactions in securities and claims (June 29,2017), available at https://www.isda.org/a/AkiDE/isda-response-to-eu-condoc-on-conflict-of-laws.pdf;

ISDA FAQ 9.1 (April 10, 2018), available at https://www.isda.org/2018/04/10/brexitfaq; pleading for a negotiated legal regime on continuity AFME, Impact of Brexit on cross-border financial services contracts (September 8, 2017), available at https://www. afme.eu/globalassets/downloads/publications/afme-brx-impact-of-brexit-on-crossborder-financial-services-contracts.pdf. ESMA warned for misuse, not referring to the private law aspects. The continuity of contracts along with market access to infrastructure are considered the main risks upon the UK's withdrawal, see ESAs Joint Committee, Report on Risks and Vulnerabilities in the EU Financial System (April 12, 2018), available at https://esas-joint-committee.europa.eu/Publications/Reports/Joint\% 20Committee\%20Risk\%20Report.pdf. There are only a handful references in applicable regulations to jurisdictional matters.

40 See IRSG, The EU's third country regimes and alternatives to passporting (January 23, 2017), p. 16; see pp. 108, 120 and 153 referring to the differences in national law: Germany is more flexible, and Luxembourg has no regulation on the point. However, as the definition of this practice will not further be a matter of domestic law, it is likely that a quite restrictive reading will prevail. 
to apply, especially when e.g. in the field of asset management, portfolios are managed on a common basis, leading i.a. to conflicts of interest.

Whether the existing provisions and practices relating to delegation, especially in the field of portfolio management are satisfactory, or need to be revised in the sense of more strictness, has been discussed in the context of the ESMA Opinion. Those in favour of more strictness - especially from the French side where vigorously opposed by the defenders of the present system, represented by the Luxembourg authority ${ }^{41}$. This discussion is part of the wide debate about the centralisation of the supervisory powers at ESMA ${ }^{42}$.

The objections by the financial supervisors are not addressed to delegation or outsourcing as such: these techniques are expressly addressed in the regulations $^{43}$, and can be used to support existing activity. This idea is translated by requiring firm to state "objective reasons" ${ }^{44}$ for the delegation. At a later stage the concern will result from the too intensive use of these techniques, leading the EU entity to become an empty box. Therefore, a balance has to be struck between permissible delegation and delegation that takes away the substance of EU located entities. The ECB e.g. has stated that it will analyse each case individually to decide whether the entity is a "real" bank, with adequate local risk management, sufficient staff, and operational independence. Back-to-back transactions are allowed but should be economically justified and not systematically lead to booking all exposures to another entity ${ }^{45}$. The condition that

41 See O. Walker, Washington joins fray over EU rules change, Financial Times (February 5, 2018); P. Jenkins, Brexit threat looms for asset managers amid fears on delegation rules, Financial Times (September 5, 2017); P. Jenkins/J. Thompson, US fund body warns of global risk from 'delegation' clash, Financial Times (November 19, 2017).

42 See A. Mooney/J. Thompson, Europe's national regulators clash over delegation, Financial Times (October 8, 2017); see also A. Bailey, supporting the Luxembourg position, and indicating that out of the $8 \mathrm{Tr}$ GBP managed in the UK, $1 \mathrm{Tr}$ are from overseas, Investment Association Annual Dinner 2017 (October 17, 2017), available at https:// www.fca.org.uk/news/speeches/investment-association-annual-dinner-2017; see Article 31a of the Commission proposal of 12 September 2018, COM(2018) 646 final.

43 Article 75 Delegated Regulation (EU) 231/2013 contains the general principles of delegation, with a special section dealing with portfolio management, essentially that the delegation is in line with the investment policy of the delegator.

44 See Article 76 Delegated Regulation (EU) 231/2013. The regulation also mentions the prohibition to delegate to the depository, or to parties with a potential conflict of interest.

45 See the Introductory Remarks by S. Lautenschläger, Member of the Executive Board of the ECB and Vice-Chair of the Supervisory Board of the ECB, for the Technical workshop for banks considering relocation in the context of Brexit, held in Frankfurt am Main on May 4, 2017, available at https://www.bankingsupervision.europa.eu/press/ speeches/date/2017/html/ssm.sp170504.en.html. 
delegation should be based on objective reasons would also allow "necessary or useful" delegation to be continued, as the Opinions only criticised excessive delegation. Ultimately, the decision will be the result of an overall supervisory assessment.

Some regulations contain interesting criteria for defining letter-box entities: this is e.g. the case in the AIFMD field, indicating conditions in which the AIFM will no longer be considered managing an $\mathrm{AIF}^{46}$.

These considerations lie at the basis of the positions which the three ESAs have adopted with respect to the issue of delegation and assimilated techniques.

\section{Positions of the regulatory and supervisory authorities as to the relocation of the UK firms to the European Union}

The three European Supervisory Authorities (ESAs) and the ECB have published individual Opinions on the conditions according to which financial institutions from the UK could further access the EU markets, after the UK's withdrawal. ESMA has published its Opinion on "General principles to support supervisory convergence in the context of the United Kingdom withdrawing from the European Union" ${ }^{47}$, which has been further detailed in three other Opinions, one dealing with investment management ${ }^{48}$, one relating to investment firms ${ }^{49}$, and a third one with secondary markets ${ }^{50}$. In addition, it has released an Opinion on the principles on the "supervisory approach to relocations from the UK" ${ }^{51}$.

46 Article 82, Delegated Regulation (EU) 231/2013.

47 ESMA Opinion 42-110-433, General principles to support supervisory convergence in the context of the United Kingdom withdrawing from the European Union (May 31, 2017).

48 ESMA Opinion 34-45-344, Opinion to support supervisory convergence in the area of investment management in the context of the United Kingdom withdrawing from the European Union (July 13, 2017). The Opinion covers mainly UCITS and AIFs, apart from the general matters under Article 1 (2) and (3) of the ESMA Regulation.

49 ESMA Opinion 35-43-762, Opinion to support supervisory convergence in the area of investment firms in the context of the United Kingdom withdrawing from the European Union (July 13, 2017). It covers all investment firms covered by MiFID II and MiFIR.

50 ESMA Opinion 70-154-270, Opinion to support supervisory convergence in the area of secondary markets in the context of the United Kingdom withdrawing from the European Union (July 13, 2017).

51 ESMA Press Release 71-99-469, ESMA Issues principles on supervisory approach to relocations from the $U K$ (May 31, 2017), covering the different multilateral trading venues regulated under MiFID I and II and MiFIR (including MTFs, OTFs). 
The EBA has published its Opinion on the issues arising from the Brexit, including a Report on insuring effective financial institutions avoiding "empty shell companies" and therefore formulating conditions for a credible location policy $^{52}$. EIOPA has made its analysis from the point of view of supervisory convergence ${ }^{53}$. The ECB has stated its position in an information document dealing with the procedures for the relocation of banks to the euro area ${ }^{54}$, while explaining in several speeches its supervisory expectations. The Council ${ }^{55}$ and the Parliament ${ }^{56}$ have also stated their views.

The context in which these statements have been drawn up widely reflects the specific situation of the UK firms, many of which were previously active as EU firms, but after Brexit will relocate to the EU. In order to be able to pursue their activity, they will have to adapt to their new status as "third country" firms, requiring to set up a fully developed organisation within the EU.

In the following summary, an overview will be given of main directions of the supervisory approach of the ESAs and the ECB and this with a view of identifying their policy guidelines. As these Opinions are often very detailed, only the elements that seem relevant for the present analysis have been mentioned. The underlying policies are largely but - relating to different segments of the financial system - not fully identical. The main concerns of the supervisors will be identified, as well as some of the specific features due to the Brexit context.

ESMA has formally stated nine principles relating to the procedure to be adopted with respect to the location of UK firms within the EU. ${ }^{57}$ Several of these principles will be further analysed in the next pages. These principles

52 EBA Op/2017/12, Opinion of the European Banking Authority on issues related to the departure of the United Kingdom from the European Union (October 12, 2017), covering credit institutions, investment firms, payment institutions, electronic money institutions, credit intermediaries and non-credit institutions admitted under the Mortgage Credit Directive.

53 EIOPA BoS-17/141, Opinion on supervisory convergence in light of the United Kingdom withdrawing from the European Union (July 11, 2017), covering insurance and reinsurance.

$54 \mathrm{ECB}$, Relocating to the euro area. Procedure for the relocation of banks to the euro area in the context of Brexit (April 13, 2017), available at https://www.bankingsupervision. europa.eu/banking/relocating/html/index.en.html

55 European Council, EUCO XT 20004/17, Guidelines following the United Kingdom's notification under Article 50 TEU (April 29, 2017),

56 European Parliament, 2017/2593(RSP), Resolution on negotiations with the United Kingdom following its notification that it intends to withdraw from the European Union (April 5, 2017).

57 ESMA Opinion 42-110-433; ESMA Press Release 71-99-469. 
have not been formally endorsed by the other ESAs, but would be largely considered applicable as well:

1. No automatic recognition of existing authorisations;

2. Authorisations granted by EU27 NCAs should be rigorous and efficient;

3. NCAs should be able to verify the objective reasons for relocation;

4. Special attention should be granted to avoid letter-box entities in the EU27;

5. Outsourcing and delegation to third countries is only possible under strict conditions;

6. NCAs should ensure that substance requirements are met;

7. NCAs should ensure sound governance of EU entities;

8. NCAs must be in a position to effectively supervise and enforce Union law; and

9. Coordination to ensure effective monitoring by ESMA.

These principles lay at the basis of the Opinion as developed by ESMA and are also largely reflected in the Opinion of the EBA and of the ECB.

\section{a) Scope of the Opinions}

These different statements not only address the pre- and post-Brexit phase and this under the proviso that no further transitional provisions will have been agreed - but also indicate the general principles relating to the access of any third country financial services firm to the EU. In that sense, they are relevant first and foremost in the Brexit context, but will also apply to any other request for access of third country groups. The statements also address the pre-Brexit phase, as UK firms are already preparing their position under the applicable EU regime: they address a range of cases, going from already established firms whose business model, range of activity and risk structure will considerably change after Brexit, to branches of UK firms which will lose access to the EU at large and may consider adopting subsidiary status, unless they prefer to limit their activity as a branch to the single member state of location. In a number of cases, the Opinions relate to cases of new establishments of UK firms who will prefer henceforth to have direct access to the EU markets. These different hypotheses are not always clearly distinguished in the Opinions, which starts from the concept that in any case the EU regime is fully applicable, will trigger the application of the entire 
regulatory apparatus - including RTS, ITS, and even ESA recommendations and will call for a detailed supervisory process from anew, but not calling for a new authorisation process for those firms already established in the $\mathrm{EU}^{58}$. Also, there is no need to develop a specific UK-related supervisory regime as it will be the one applicable to any third country applicant.

These Opinions express the main points of the supervisory practice as it exists today in the directives and regulations. Technically these Opinions cannot derogate from the directives and regulations on which today's supervisory practice is based, but in practice they are in specific instances, stricter or more detailed, an approach which most of the time can be justified by the actual practice of today's supervision. According to one leading source, the ESMA Opinions reflect a "tougher appraisal of licence applications. EU regulators may note the change of tone but continue to review relocation applications in accordance with their current approach" ${ }^{59}$.

The question arises to what extent the supervisory practices detailed in the Opinions are also applicable to existing firms already located in the EU and whose legal structure - e.g. as a subsidiary - will not be changed. To the extent that the Opinions reflect existing practice, this question might not be very relevant but in most fields, the stricter appreciation provided in the Opinion should logically also affect the existing firms, whether in the context of a relocation or not. In the absence of specific regulation dealing with the case of a Member State leaving the Union, the same rules should apply to the continuation of the same financial activity.

A related but different question arises when a credit institution transfers its seat to another EU or third country jurisdiction while the legal entity is unchanged. As the authorisations of credit institutions are based on national law, this cross-border transfer of the seat may - depending on the applicable laws ${ }^{60}-$ imply continuity of the legal person, but not of the authorisation, which is rooted in the national laws of the two jurisdictions involved. There is up to now no Europe-wide banking authorisation.

58 This explains the statement that NCAs and applicants should not rely on the decisions of other competent authorities, cf. EBA Op/2017/12, pp. 5-6 (no. 15, $2^{\text {nd }}$ point).

59 See Clifford Chance, Brexit: ESMA signals tougher stance on UK asset manager relocation to the EU (July 20, 2017), available at https://www.cliffordchance.com/briefings/ 2017/07/brexit_esma_signalstougherstanceonukasse.html.

60 European Company Law has - yet - not adopted a EU wide approach to transfer of the seat, except for a European Company (SE); see Article 8 SE-Regulation (EC) 2157/ 2001. 


\section{b) Addressees of the Opinions}

These "Opinions" are statements addressed by the European Supervisory Authorities (ESAs) to the national competent authorities, indicating the topics which they will have to analyse in more detail in the requests for access to the EU markets from UK firms. The Opinions are therefore addressed first to the national competent authorities in the context of fostering a common supervisory culture ${ }^{61}$ and more widely to the European institutions (Parliament, Council and Commission) with a view of "contributing to the establishment of high-quality common regulatory and supervisory standards and practices"62 especially in the perspective of enhancing supervisory convergence ${ }^{63}$.

As these Opinions have been adopted in the respective ESAs, one can presume that they will be followed up in the respective supervisory practice of each of their members. The 2017 proposed amendments to the ESA regulations clarify that the Authority will monitor the Opinions, along with the guidelines and recommendations, to verify that the arrangements on outsourcing, delegation and risk transfer are in accordance with Union $\operatorname{law}^{64}$. In case a national authority refuses to follow up the ESA recommendation, the reasons for the refusal and the recommendation of the ESA will be made public.

One could qualify these Opinions as the informed views as agreed by the national authorities on the issues to be dealt with pre- and post-Brexit, coordinated at the level of the ESAs. Although it is unclear to what extent these Opinions have formally been coordinated with the Commission, they express the common views of the regulatory community. Also striking is the absence of references to the role of the ECB.

61 Article 29 (1) (a) ESMA, EBA and EIOPA Regulation. The EBA opinion also mentions the Parliament, the Council and the Commission as addressees, as well as the ECB and the SRB. It includes the NCAs of the EEA-EFTA states among its addressees.

62 See Article 8 (a) EBA Regulation. The EBA opinion is addressed to the NCAs and to the Commission.

63 On the background, one can perceive concerns about competition among the MS for new locations of financial services firms.

64 See Article 31a of the Proposal for a Regulation of the European Parliament and of the Council Amending Regulation (EU) No 093/2010 (September 20, 2017), COM (2017) 536 final: "Coordination on delegation and outsourcing of activities as well as of risk transfers”. 


\section{c) Full application of the EU regime}

Dealing with the core aspects of the regulation in their respective fields, the Opinions stress the full application of the authorisation procedures: all requirements have to be met, even those that have not yet been adopted by the Commis$\operatorname{sion}^{65}$. There will be no shortcuts and the previous Opinions of other NCAs or other authorities ${ }^{66}$ will not be considered decisive, but where necessary the existing licence will have to be reviewed and upgraded due to the change in nature or increase in the business activity making additional or stricter conditions becoming applicable. A thorough analysis of the present and future business activities will lead to a reappraisal of the business, its structure, governance, management, staffing ${ }^{67}$, internally special risk procedures, commercial policies, etc. Resolution and deposit guarantee regimes and their possible limitations are also to be considered. Some flexibility seems to have been considered, when the Opinion states that "the status of applicable regulations and practices in the UK may be taken into account", sometimes even leading to waivers ${ }^{68}$. Elements relating to the relocation would not qualify.

\section{d) Common concern: letter box companies}

A quite predominant, recurrent consideration in the Opinions is the concern that former or new UK firms would be managed as "empty shells", or as "letter box companies" or "brass plate firms". This concern has also been mentioned in several directives ${ }^{69}$ and is here translated in a whole series of more detailed warnings or statements, some of which will be quite incisive. The concern is expressed in the overarching statement that the applicants will have to state objective factors to justify their choice for a certain jurisdiction ${ }^{70}$, for a certain organisational structure, for the proposed governance regime, in other words

65 EBA Op/2017/12, p. 23 (no. 17).

66 Even by mutual recognition: EBA Op/2017/12, p. 23 (no. 17).

67 See ECB, Brexit: an ECB supervision perspective (November 15, 2017), available at https://www.bankingsupervision.europa.eu/press/publications/newsletter/2017/html/ ssm.nl171115_2.en.html: “dual hatting” raises concern as to independence of the function, conflicts of interest and insufficient time commitment.

68 See e.g. EBA Op/2017/12, p. 25 (no. 23) on the coordination of laws, regulations and administrative provisions relating to undertakings for collective investment in transferable securities (UCITS); Article 20 AIFMD.

69 Recital 16 and Article 13 Directive 2009/65/EC; Recital 83 and Article 20 AIFMD.

70 ESMA Opinion 35-43-762, p. 3 (no. 12), p. 9 (no. 34); see also p. 12 (no. 45) for the cost savings argument; idem for delegation to non-EU entities. The "objective choice" idea was already part of some directives. 
that their proposal does not constitute a device for evading or circumventing the existing access restrictions, to engage in regulatory arbitrage, or more positively will result in a genuine financial services firm which is part of the EU financial system. The same idea has been stated in ECB statements ${ }^{71}$.

This reference to "objective factors" of choice both for the jurisdictions and for the structure of the firm in the EU can be considered a safeguard for the applicant's commitment to play a role in the EU markets, as a call for his acceptance of the rules applicable in the host country. The principle is clearly stated in the EBA, the ESMA Opinions and very strongly in the ECB statements and is further developed in many specific recommendations, going from the governance of the applicants, their risk management, their internal structure, including their outsourcing and delegation. The EBA Opinion makes a nuanced statement as to how back-to-back and intragroup dealings have to be dealt with as part of a separate legal entity. There should not be an outright prohibition, but a stronger attention from risk management, including on counterparty risk ${ }^{72}$, drawing attention to possible risk considerations. A comparable statement was published by the UK PRA ${ }^{73}$.

\section{e) Subsidiaries or branches}

The Opinions first address the requirements applicable to subsidiaries of UK institutions, which for credit institutions is the full regulatory regime applicable to all credit institutions, coordinated by the ECB's final authorisation right.

Branches of UK credit institutions will be subject to the requirements as established by the local legislation and supervision of the state where the branch is located. They often differ from state to state: the CRD IV only requires that States do no engage in regulatory competition by adopting a regime that is more favourable than that of branches of $\mathrm{EU}$ institutions ${ }^{74}$. As to the differences between EU states, a regime providing for an identical treatment EU wide has been mentioned in the CRD IV but has not been implemented, leaving some room for competition among Member States. The activity of

71 See ECB, Brexit: an ECB supervision perspective (November 15, 2017), available at https://www.bankingsupervision.europa.eu/press/publications/newsletter/2017/html/ ssm.nl171115_2.en.html.

72 See the list of conditions in EBA Op/2017/12, p. 15.

73 PRA Consultation Paper CP 29/17, International banks: the Prudential Regulation Authority's approach to branch authorisation and supervision (December 2017), p. 27 Box 5 on booking arrangements.

74 Article 47 CRD IV. 
these branches is in any case limited to their state of location. De facto, this may lead to a preference for the constitution of subsidiaries rather than branches, as the former enjoy the EU passport, but would imply the application of the full EU regulation. The financial authorities also prefer subsidiaries, as the financial position of these firms and the applicable regulations would be more clearly defined, stricter management provisions apply and more own funds would be available. Also, the relations with the supervisory authorities in the state of origin should be based on a more clearly defined equal basis.

Depending on their specific business activity or model, it is likely that some subsidiaries of UK banks will reach the criteria for qualifying as an SSM bank and hence be subject to direct ECB supervision ${ }^{75}$. Up to now, no comparable regime applies to subsidiaries of investment firms in the absence of an EU wide supervisory regime: hence these will remain subject to the regulation and supervision of the firm's home state ${ }^{76}$. Recently EBA and ECB have published statements to declare the SSM framework in part applicable to significant investment firms, while the Commission plans to propose regulation on this topic $\mathrm{c}^{77}$.

According to the applicable regulation ${ }^{78}$, third country investment firms - both subsidiaries and branches - are subject to the host state's regulation and supervision and the activity of their branches is limited to that state. It is often considered too expensive and burdensome to create a subsidiary for investment firm activity, although in that case it would benefit from the European passport ${ }^{79}$.

75 The criteria of Article 6 SSM-Regulation address the credit institution on a consolidated basis, including the UK entities pre-Brexit. Post-Brexit significant institutions may become less significant as only EU entities will be included in the EU supervision.

76 See Article 6 (3) MiFID II; see also Article 3 (c): national exemption of order transmission activity to third countries.

77 See EBA Op/2017/12, p. 5 (iv); EBA Op/2017/11, Opinion of the European Banking Authority in response to the European Commission's Call for Advice on Investment Firms (September 29, 2017); European Commission, Review of the prudential framework for investment firms (December 20, 2017), available at https://ec.europa.eu/info/ publications/171220-investment-firms-review_en, with proposals for a regulation and a directive (COM(2017) 791 final); Proposal for a Regulation on the prudential requirements of investment firms and amending Regulations (EU) No 575/2013, (EU) No 600/ 2014 and (EU) No 1093/2010 (December 20, 2017), COM(2017) 790 final; ECB, Opinion on the review of prudential treatment of investment firms (CON/2018/36) (August 22, 2018), available at https://www.bankingsupervision.europa.eu/ecb/legal/ pdf/en_con_2018_36_f_sign.pdf.

78 For Credit institutions on the basis of CRD IV; for investment firms the regime has changed starting 2018 on the basis of MiFID II.

79 Downsides of the subsidiary format include requirements in terms of legal capital, dedicated staff, systems and controls, local supervision, and expensive and time-con- 


\section{f) Main requirements to be applied to UK firms locating in the EU}

The Opinions present the subject by describing the conditions and procedures for authorising a bank, an investment firm, or depending on the case, investment managers, secondary markets, or insurance firms. The following main topics are summarised here in some detail:

- Authorisation

- Governance

- Internal controls

- Delegation and outsourcing.

\section{(i) Authorisation}

The Opinions distinguish firms which have already been authorised, but whose status changes from EU firms to non-EU firms, and those which apply for a new authorisation, for which the existing EU rules will apply ${ }^{80}$. In both the $\mathrm{EBA}^{81}$ and the ESMA Opinion, it is made clear that subsidiaries will not have to be re-authorised, but that the firms will not be allowed to merely rely on the existing authorisation. Their position will have to be reviewed on the basis of the new actual or proposed business model and plans, which may lead to a considerable business expansion, needing additional means in terms of organisation, especially risk management. The proposed business entity should correspond to the envisaged activity in terms of size, nature, and complexity. A reassessment of the existing organisation, governance, business model and business plan will be undertaken. New issues will receive special attention, such as the effect of a non-EU management, the qualification of significant shareholders, or the relations with a non-EU group. Group relations with non-EU parties deserve special attention ${ }^{82}$.

The freedom of establishment or of services is extended to "financial institutions" other than credit institutions which are part of a group led by a credit institution governed by EU law. The financial institution should be $90 \%$ owned by the credit institution, and fully guaranteed by the latter. Once as a

suming authorization process, cf. IRSG, The EU's third country regimes and alternatives to passporting (January 23, 2017), p. 121 (at 7.12).

80 See ESMA Opinion 42-110-433.

81 EBA Op/2017/12, p. 24 (no. 17); ESMA Opinion 34-45-344, p. 3 (no. 11) mentioning that there are no transitional provisions.

82 ESMA Opinion 34-45-344, p. 3 (no. 13). 
consequence of Brexit the parent is no longer an EU entity, this special regime would come to an end, the subsidiary will lose its privilege to be able to offer banking services as defined ${ }^{83}$.

The Opinions also state that applicants for an authorisation will not be able to rely on previous or existing authorisations, whether from another Member State or from a third country ${ }^{84}$. This especially refers to applications from firms formerly authorised in the UK or active in the EU as branches. But their file in the UK could usefully be submitted to the authority in the new State of location, mainly for informative purposes.

NCAs are invited to monitor developments of UK law, and be alert for differences that may affect equivalence or change the risk profile. In the absence of cooperation agreements providing for a mutual information duty, this task will best be exercised by the ESAs, and be applicable to all relevant third countries.

With respect to new authorisations the reasons for the choice of the jurisdiction have to be stated and will be assessed by the national authority. This may be one of the decisive elements for refusing access, on the basis that the choice is determined by opportunistic motives, possibly by regulatory competition, or by an attempt to evade stricter standards $s^{85}$.

But whether the national authority would be entitled to state other grounds on which the access will be refused, including on the basis of that state's policies, or for political reasons, will depend on its national legislation. Overbanking e.g. could become a valid ground for refusing access, but the present EU legislation does not provide an adequate legal basis for deciding $\mathrm{so}^{86}$. The level playing field would be seriously jeopardised in case political reasons would determine the authorisation of financial institutions within the EU, but this does not apply in relation to third countries.

\section{(ii) Governance}

The governance of both existing and new entities receives considerable attention. The central idea is that the firm will be required to dispose of an effective and sound governance structure in the $\mathrm{EU}^{87}$, capable of performing their

83 See the regime of Article 34 CRD IV.

84 EBA Op/2017/12, p. 24 (no. 17).

85 EBA Op/2017/12, p. 25. Where applicable, the ECB will apply the same reasoning.

86 H. Jones, A. MacAskill, and A. Davies, EU watchdog urges 'overbanking' solution to start local, Reuters (September 27, 2017), available at https://uk.reuters.com/article/uksummit-regulation-enria-banks/eu-watchdog-urges-overbanking-solution-to-start-local-idUKKCN1C21FC.

87 EBA Op/2017/12, p. 44 (no. 105). 
functions, both in terms of management functions and in terms of internal risks controls. The EU firm should be an independent entity managed in its own interest. The management - or directors - will, as ultimate decision makers, have collective responsibility and should effectively be in charge of decision making and not merely rely on the instructions of the parent company. They should have a "meaningful presence" in the chosen jurisdiction and be available for interaction with the supervisors ${ }^{88}$. Some statements point to a residence requirement ${ }^{89}$. Therefore, the number of top management should be adequate in terms of numbers - at least two for asset management, ${ }^{90}$ and composition, and dedicate sufficient time to their professional duties. The number of outside positions of directors should therefore be limited, to avoid too strong group influence but also to avoid conflicts of interest ${ }^{91}$.

In the investment management sector, the directors will have to be attributed specific responsibilities, which they should exercise personally, without delegation, but remaining collectively responsible. There will be no reporting lines to group functions ${ }^{92}$. Directors will have to be available for the firm, and dedicate sufficient time to it, what would be incompatible with a large number of outside directorships. Also, a local presence is expected, implying availability for the supervisors during normal business hours. A local domicile is not strictly mandated, although in some jurisdictions this may flow from the rules on establishment ${ }^{93}$. The firms should also have a sufficient operational set-up and dispose of appropriate human resources and technical resources ${ }^{94}$.

\section{(iii) Internal governance and controls}

The adequacy of the structures and governance put in place will be assessed from the relocation perspective, with - the principal element in the assessment-

88 For UCITS it is reminded that head office and registered office have to be in the same location: Article 7 (1) (d) Directive 2009/65/EC; see ESMA Opinion 34-45-344, p. 4 (no. 16).

89 ESMA Opinion 42-110-433, p. 6 (no. 38): key executives and senior managers should be "employed in the Member State of establishment and work there to a degree proportionate to their envisaged role, if not on a full-time basis". Cf. ESMA Opinion 34-45344 , p. 7 (no. 28): presence during normal business hours.

90 ESMA Opinion 34-45-344, p. 4 (no. 16).

91 See about these aspects ESMA Opinion 35-43-762, pp. 4-6 (no. 14-22); ESMA Opinion $34-45-344$, p. 5 (no. 23).

92 ESMA Opinion 35-43-762, p. 5 (no. 18-20); compare the Senior Managers Regime in the UK (sub C.1.).

93 Residence requirements exceptionally apply to company directors or managers in general in some jurisdictions such as in Italian law for third country executives and in Swiss law.

94 ESMA Opinion 35-43-762, p. 4 (no. 13). 
special attention for the objective reasons for this decision. The structure of its local risk management should be commensurate to size, nature and complexity of the proposed business activity ${ }^{95}$.

Reporting lines to the group should not impair the independence of the internal control and compliance functions, which should function on the basis of the separate entity and be internally separated ${ }^{96}$, and reporting lines to group control functions should not impair independence ${ }^{97}$.

The necessary internal controls have to be available, with as a minimum the compliance and risk functions. Material legal risks have to be assessed by an independent party and in general, risks have to be reported to the board and to the supervisors. In the banking sector, an elaborate analysis of the risk models is required: these will remain applicable, unless a change in the business or volume of its activity has intervened. The EBA Opinion analyses the different cases in which internal models can further be used or will be submitted to a new analysis and authorisation procedure by the EU authority ${ }^{98}$. Delegation of control functions within the same group calls for effective conflict of interest management ${ }^{99}$. They may have to be calibrated following detailed criteria ${ }^{100}$.

\section{(iv) Delegation and outsourcing}

The developments in the Opinions on delegation and outsourcing are particularly relevant as these techniques may lay at the basis of the much decried "empty shell" of "letter box companies" and other forms of circumvention of the EU rules. In general terms, delegation and outsourcing are permissible if based on objective reasons, on a limited scale, and without putting oversight in danger. In the asset management field, investor protection remains the paramount objective.

Delegation should be based on identifiable objective reasons ${ }^{101}$, chosen on the basis of a thorough analysis, taking into account its materiality. The delegate

95 ESMA Opinion 34-45-344 contains a long list of criteria for applicant assessment by the NCAs. Attention to AML/CTF considerations is mentioned.

96 ESMA Opinion 35-43-762, p. 5 (no. 19 et seq.); ESMA Opinion 34-45-344, pp. 7-8 (no. 31) prescribing guidelines for assessing material legal risks and how external legal advisors should be designated.

97 ESMA Opinion 34-45-344, p. 5 (no. 20).

98 EBA Op/2017/12, p. 40 (no. 99); see EBA RTS/2016/03, Final Draft Regulatory Technical Standards (July 21, 2016).

99 ESMA Opinion 34-45-344, p. 16 (no. 66).

100 See ESMA Opinion 34-45-344, p. 6 (no. 25).

101 See Article 76 Delegated Regulation (EU) 231/2013; ESMA Opinion 34-45-344, p. 10 (no. 43): if cost saving is argued, evidence for it should be provided; see also Article 82 
should be the most suitable for undertaking the delegated function ${ }^{102}$, located in a jurisdiction chosen on objective grounds, and be able to comply with the applicable EU regulations ${ }^{103}$. If cost savings are argued, these should be proved. The same applies to outsourcing: objective reasons, with a limited scope, especially if it relates to critical functions and if not satisfactory may even have to be phased out ${ }^{104}$. For intra-group outsourcing, special attention is due because of conflicts of interest ${ }^{105}$. Sufficient oversight mechanisms have to be provided ${ }^{106}$.

Delegation to non-EU entities calls for special attention. The most delicate aspect relates to the delegation to a non-EU service provider of the "functions relating to the investment service of portfolio management" of investment firms: this delegation is authorised but subject to some general conditions such as the authorisation of the third country service provider in its jurisdiction, effective supervision by its competent authority and the existence of a cooperation agreement between competent authorities, providing for exchange of information, and cooperation for enforcement purposes. Delegation of investment management for UCITS management companies has a regulatory ba$\operatorname{sis}^{107}$, but it should not exceed by a substantial margin the investment management functions performed internally: there should at least be some investment management present in the state where the fund is located and this for each individual fund ${ }^{108}$. This fund should have at least some senior management or staff to follow up on the performance of portfolio management or risk management. One should remind that a separate regime applies to outsourcing of the depositary function, as the first line depositary remains strictly liable for the restitution of funds and securities: here again the regulation reminds that these cases of delegation should not result in the management company becoming a letter box entity ${ }^{109}$. This approach should apply to both new, UK

(1) (d) Delegated Regulation (EU) 231/2013 listing criteria for permissible delegation, including the case that the delegated activity would "exceed by a substantial margin the management functions performed by the AIFM itself”.

102 ESMA Opinion 34-45-344, p. 12 (no. 50).

103 ESMA Opinion 34-45-344, p. 10 (no. 49).

104 ESMA Opinion 35-43-762, p. 9 (no. 34 and 36).

105 ESMA Opinion 35-43-762, p. 9 (no. 36).

106 See for the details, ESMA Opinion 35-43-762, pp. 11-12 (no. 44).

107 See for the conditions for delegation to third country service providers: Article 32 Delegated Regulation (EU) 2017/565; compare Article 13 UCITS-Directive, according to which delegation of the management company own functions is subject to the home Member state law.

108 ESMA Opinion 34-45-344, p. 13 (no. 56).

109 Article 13 (2) Directive 2009/65/EC. 
originated funds as to existing ones, in the latter case under the form of supervisory reassessment ${ }^{110}$.

These provisions address all EU funds, irrespective of the jurisdiction where the delegated functions will be exercised. The basic idea, also voiced in the field of banking supervision, is that local "substance" should remain ${ }^{111}$, implying i.a. sufficient activity and staff ${ }^{112}$. A similar approach addresses the outsourcing of functions by EU trading venues ${ }^{113}$. EU venues should not become letter-box entities, and the coordination between the EU venue and the non-EU outsourced venue should remain ensured ${ }^{114}$. Some operational functions should not be delegated to non-EU venues, such as the responsibility for suspensions, removal of instruments, or trading halts ${ }^{115}$.

Internal control should be risk based and allow for on-site inspections ${ }^{116}$. In the same vein, the ESMA opinion reminds the application of the "best execution" principle: the choice for an execution venue should be based on objective elements. The choice for a single execution venue or to an affiliate party may call for additional monitoring in view of the best execution requirement.

\section{(v) Relocation policy}

The Opinion published by the ESAs state the conditions which non-EU firms - especially UK firms - will have to meet to be allowed to exercise financial services activities in the EU. The Opinions draw attention to the role of the EU National competent authorities which are expected to give high priority to these location requests, exposing the main points of attention. The basic rule is the full application of the EU laws and regulations to these entities and for already established entities, to be adapted in light of their changed activity. They do not mention the right of Member States to refuse access to non-EU firms. This is translated by stating that applicable regimes will be

110 ESMA Opinion 34-45-344, p. 15 (no. 62).

111 See ECB, Brexit: an ECB supervision perspective (November 15, 2017), available at https://www.bankingsupervision.europa.eu/press/publications/newsletter/2017/ html/ssm.nl171115_2.en.html; ESMA Opinion 34-45-344, p. 13 (no. 56): no wider delegation than the usual internal activities. Recital 16 CRD IV mainly draws attention to regulatory arbitrage.

112 ESMA Opinion 34-45-344, p. 14 (no. 60): three local FTE for portfolio management and/or risk management and monitoring of delegates; in case of relocation sufficient activity is to be transferred to the EU delegate state (no. 61).

113 See ESMA Opinion 70-154-270.

114 E.g. ESMA Opinion 70-154-270, p. (no. 30) on suspension or removal from trading.

115 But the technical arrangements can be located outside the EU, see ESMA Opinion 70154-270, p. 5-6 (no. 30).

116 See ESMA Opinion 35-43-762, p. 10 (no. 40). 
applied on the basis of the "objective reasons" for relocation: the fundamental option remains that third country firms may lawfully become - or remain active in the EU.

Nevertheless, the ESMA statement is revealing: "NCAs should reject any relocation request creating letter-box entities where, for instance, extensive use of outsourcing and delegation is foreseen with the intention of benefitting from an EU passport, while essentially performing all substantial activities or functions outside the EU27"117. One could qualify this as abuse of the access rights.

As freedom of establishment will not further apply, it will be up to the NCAs to develop their own policies as to the location or relocation of UK firms. The Opinions aim to contribute to supervisory coherence ${ }^{118}$, what in fact also stands for avoiding regulatory competition and resulting arbitrage.

The Opinions express a strong concern that non-EU firms may take advantage of the NCA's openness. This concern is expressed in many ways, most frequently in the repeated reference to "letter-box entities", "empty shells", or "brass plate firms". Generally, it is up to the NCA to draw the balance between the objective reasons for locating to its jurisdiction compared to the not credible ways as evidenced in its internal organisation Specific criteria are mentioned: in the Opinion on asset management, ESMA refers to the relocation of a sufficient amount of the portfolios managed and relating risk management functions, also referring to availability of a supporting organisation such as financially experienced and supporting staff. NCAs should also be attentive to the need for an efficient organisation of the financial activity and should only come to a negative conclusion when the balance has become too much out of kilter. How to test the genuineness of an applicant's intention will remain difficult: stating the reasons for the choice and indicating the ways the proposed objective will be achieved, should allow to eliminate the most blatant cases.

On the basis of the regulatory provision that head office and registered office should be in the same member state ${ }^{119}$, the ESMA opinion goes in very specific detail about the internal organisation, required the main functions to be developed locally and even calling for the physical presence of at least two senior managers and relevant staff -3 local FTEs. ${ }^{120}$ These detailed assessment criteria

117 ESMA Opinion 42-110-433, p. 5 (no. 28). See also no. 35: key function activities in the EU.

118 To be mentioned here is the ESMA initiative to create a Supervisory Coordination Network as a tool for monitoring national positions, ESMA Opinion 35-43-762, p. 2 (no. 7).

119 See supra fn. 88.

120 See ESMA Opinion 34-45-344, p, 9 (no. 36 et seq., esp. no. 60); see also the comments on the so-called "white-label business", p. 9 (no. 37); Similar concerns led to strong 
have however to be considered in the overall context of the effectiveness of the local entity.

The interests involved in these cases go beyond the technical application of the existing EU regulations. They ultimately concern wider policy objectives, such as the orderly functioning of the markets, the maintaining of a high degree of investor protection, the confidence in the financial systems, containing risk developments especially at the systemic level or when imported from other jurisdictions. But beyond these traditional objectives of financial regulation, one should not deny that competition for market share, involving states and supervisors, their markets and their operators are the significant drivers behind these opinions ${ }^{121}$. Tightening access to EU markets without blocking it, may contribute to achieve a balanced outcome in the interest of all parties concerned.

\section{(vi) Non-EU Branches of EU firms}

The ESMA Opinions on Investment firms and Asset management deal with the case in which EU located firms, e.g. a subsidiary of a UK firm, establish a branch outside the EU, e.g. in the UK, from which UK based activity could be developed. In principle, there should be no objection against this scheme, which is a matter that mainly relates to the establishment in the UK. However, branches of EU banks in non-EU jurisdictions should be authorised by the home state (EU) supervisor. Moreover, the real concern relates to the risks that this scheme might create specific letter-box risks. The opening of these nonEU branches should be based on objective reasons, related to the services in these non-EU jurisdictions, e.g. for organising marketing support ${ }^{122}$.

Firms may use technical legal instruments to locate activities outside the EU: in these cases, activity is outsourced, or is delegated to a non-EU entity. This may take the form of back-to-back transactions ${ }^{123}$ and should not be used to service back the EU firm's activities or its clients to the UK acting through its branch. Specific oversight by the NCAs is called for.

statements from the ECB about the banks' slow progress in establishing an effective presence in the EU, especially in the field of risk management.

121 See among many: S. Khan, The EU is ready to reap the profits from our financial services and there's nothing we can do. The Independent (March 25, 2018), available at https://www.independent.co.uk/voices/financial-services-city-london-european-union-lch-lse-euro-clearing-ecb-brexit-latest-a8272356.html.

122 See ESMA Opinion 35-43-762, p. 13 (no. 49); a similar recommendation in ESMA Opinion 70-154-270, p. 6 (no. 35); and ESMA Opinion 34-45-344, p. 16 (no. 68); effective supervision of the branch is required.

123 See EBA Op/2017/12, pp. 47 et seq. (no. 120 et seq.) including intragroup transactions. 
The IRSG, a group organised by CityUK, took a more liberal attitude ${ }^{124}$. But at the end only courts can tell.

\section{EU firms established in the UK}

\section{Banking supervision: The Prudential Regulatory Authority PRA}

Before Brexit, EU firms established in the UK could operate under the freedom of establishment and hence carry out their activity as branches, which was the preferred mode of operation, allowing for maximum flexibility, lower costs and sometimes allowing for a rather modest presence both in terms of staff and of funding. Financial supervision was exercised by the home authority and cooperation agreements with the UK authorities were in place. This regime will not be continued and firms will have to apply for an authorisation from the Prudential Regulatory Authority (PRA), whether as a UK bank, in which case requirements applicable to UK banks will apply, or as a branch of an "overseas" bank. About 77 EEA banks will have to apply to the PRA for a new licence, a process that would take about 12 months. This would take a considerable time, and therefore some "grandfathering" has been proposed, provisionally continuing the existing licence ${ }^{125}$, as otherwise the customers may be lost and the markets disrupted.

Since 2016, the Senior Managers Regime aimed at increasing personal responsibility of manager in the financial services industry was introduced, applicable to all banks, to certain PRA designated investment firms and to the UK branches of foreign banks. From December 2019 it will be extended to all financial services firms, irrespective of their size. This regime is composed of three elements: (i) the Senior Managers Regime ${ }^{126}$, applicable to larger firms; every senior manager should sign a 'statement of responsibilities' clearly identifying his responsibilities and his accountability, and this notwithstanding his overall responsibility for the firms functions and activities. The firm has to declare that the manager is suitable to exercise the stated functions. At least once a year, firms need to certify that senior managers are suitable to do their jobs: (ii) the Certification Regime, which applies at all 'material risk-takers' in a firm, requiring them to be fit and

124 IRSG, The EU's third country regimes and alternatives to passporting (January 23, 2017), p. 122 (at 7.15).

125 H. Jones, Bankers call on Bank of England to act fast on EU branches, Reuters (December 11, 2017), available at https://uk.reuters.com/article/uk-britain-eu-banks/ bankers-call-on-bank-of-england-to-act-fast-on-eu-branches-idUKKBN1E51EG.

126 FCA, Senior Managers and Certification Regime: banking (July 26, 2017), available at https://www.fca.org.uk/firms/senior-managers-certification-regime/banking. 
proper to perform the function; (iii) the rules of Conduct, applicable to both senior managers and material risk-takers. Less well known is that banks should include a whistleblowing policy into their code of conduct ${ }^{127}$. Also, foreign banks with a small business activity might be exempted.

One should also mention the "overseas persons" regime, allowing firms which do not have a permanent place of business in the UK, but are located in the EU, or in other jurisdictions (e.g. the US), to undertake certain financial service activities in the UK. The exemption is narrowly defined and includes dealing in investments, as principal or as agent, arranging investments deals or advising thereon, but also operating a multilateral trading facility.

The Bank of England would receive additional powers to supervise non-UK $\mathrm{CCPs}^{128}$ and CSDs.

After Brexit the need for cooperation with the EU supervisory bodies will become increasingly urgent ${ }^{129}$

\section{Investment firms and market supervision: The Financial Consumer Authority}

After Brexit, and absent any agreement to the contrary, EU investment firms could be active in the UK market whether as a subsidiary or as a branch. It can be expected that the UK will apply to these firms a third-country regime, as defined in UK law, in this case the Financial Services and Markets Act 2000 (FSMA) $)^{130}$ which will be substantially similar to the MiFID II regime, EU

127 FCA, Whistleblowing in UK branches of foreign banks: Response to Consultation Paper 16/25 (May 3, 2017), available at https://www.fca.org.uk/publication/policy/ ps17-07.pdf.

128 The bank of England anticipates that, at the point of exit, the UK authorities will apply the recognition regime currently in force in the EU", see BoE, The Bank of England's approach to the authorisation and supervision of international banks, insurers and central counterparties (December 20, 2017), consultation papers available at https:// www.bankofengland.co.uk/news/2017/december/approach-to-authorisation-andsupervision-of-international-banks-insurers-central-counterparties. For the post-consultation statement see PRA Policy Statement PS 3/18, International banks: the Prudential Regulation Authority's approach to branch authorisation and supervision, (March 28, 2018), available at https://www.bankofengland.co.uk/-/media/boe/files/ prudential-regulation/policy-statement/2018/ps318.pdf.

129 See ECB, ECB and BoE convene joint technical working group on Brexit-related risks (April 27, 2018), available at https://www.ecb.europa.eu/press/pr/date/2018/html/ecb. pr180427_5.en.html.

130 Available online at https://www.legislation.gov.uk/ukpga/2000/8/contents. 
firms being treated as third-country firms. Until further changes in the FSMA this would mean that the substantive regulatory regime as laid down in the MiFID II would be applicable, except for the institutional framework. Transactions with retail clients or professional counterparties will be allowed for firms that have established a branch and have been authorised in the $\mathrm{UK}^{131}$, and meet the other conditions of MiFID II, as governed by UK law. These conditions relate i.a. to the requirement to have, as a branch, sufficient capital - or own funds - and respect the FATF anti-money laundering rules and the OECD Model tax convention. Several aspects of the MiFID II regime will have to be adapted in the corresponding UK regulation, such as the arrangements for cooperation with the EU supervisors and the exchange of information $^{132}$.

Third-country investment firms were authorized by the FCA under the MiFID I regime applying the EU rules under a reciprocity regime, Article 15. Their activity would be limited to the state of establishment. In some cases, they could avail themselves of the exemptions provided in the directive limiting their activity, Articles 2 and 3. The Bank of England extended its supervision to the larger investment firms meeting certain risk related conditions, called "Eligible Investment Firms". This refers especially to firms acting as a principal in investments and would be required to have a minimum capital of 730.000 euro, which is also the EU threshold ${ }^{133}$. The firms viewed are those with a 15 billion GBP balance sheet or are part of a PRA regulated group. Under MiFID II, this regime will generally have to conform to the requirements of that directive with respect to third country branches, but the consequences would not be materially different ${ }^{134}$. Mention can be made of the "reversed solicitation"135 exception, considered especially relevant for UK firms intending to be active in the EU.

131 This is different from Article 39 (2) FSMA, where home country authorisation would be required.

132 HM Treasury, Transposition of the Markets in Financial Instruments Directive II (March 26, 2015), available at https://assets.publishing.service.gov.uk/government/uploads/system/uploads/attachment_data/file/418281/PU_1750_MiFID_II_26.03.15. pdf, pp. 9 et seq.

133 PRA Statement of Policy, Designation of investment firms for prudential supervision by the Prudential Regulation Authority (March 25, 2013), on the basis of Article 8 FSMA.

134 Compare Article 39 MiFID II.

135 Article 42 MiFID II: "Provisions of services at the exclusive initiative to the client". 


\section{Statements about future supervisory practice}

As is the case for the EU Supervisory Authorities, the UK authorities have also published the policies and approaches they intend to follow after Brexit. During the implementation period, they consider that the EU regulation would remain applicable and indicate the need for appropriate cooperation between the EU authorities.

The PRA has published a consultation paper outlining its future approach to international banks operating in the UK, especially after the Brexit. It also contains the basic elements applicable to all foreign banks. Firms under the passport would have to adapt to the classification of the banks in different categories of activity and risk. EU branches formally active as "passported" branches will need to be authorised in the UK.

In the case of designated investment firms, establishment could take the form of a subsidiary or of a branch. Their dual authorised form should apply for authorisation from the BoE. The procedures are quite lengthy, 6 to 12 months according to the FCA. Fit and proper rules will apply to the entire firm.

With respect to the larger non-UK banks, the subsidiary format may also be required. The decisive criterion would be whether their home supervisory standards are considered equivalent and meeting supervisory expectations as formulated by the PRA ${ }^{136}$, while sufficient supervisory cooperation is in place, or meeting the PRA's criteria of supervisibility.

The third category are the systemically important or "wholesale" banks: these may be allowed to continue to operate as a branch and subject to home state supervision ${ }^{137}$, provided the PRA is satisfied on a number of supervisory criteria: higher degree of supervisory cooperation, greater assurance on resolution arrangements with stronger involvement of the PRA in terms of influence and visibility, extending to the entire banking group. Size, complexity and interconnectedness are mentioned as criteria: 15 bn GBP gross assets in the UK, type of activity ${ }^{138}$. If these supervisory conditions have not been met or would be ineffective as compared to the UK ones, the PRA would require to apply specific regulatory requirements to the branch, or require the bank to adopt the subsidiary format, to be supervised on a

136 PRA, Consultation Paper CP29/17, pp. 27 et seq. (at 5.10) and Supervisory Statement 1/18 (March 28, 2018).

137 PRA, Consultation Paper CP29/17, p. 11 (at 2.11).

138 Defined in the basis of the Critical Functions as defined in Supervisory Statement 10/ 14 as "Critical Economic Functions", see PRA, Consultation Paper CP29/17, p. 10 (at 2.10). 
standalone basis, with the application of a Multiple Point of Entry regime for resolution.

On the basis of the present experience, the PRA would expect non-EEA international banks active as wholesale branches not to be affected and to be able to further operate as a branch. This would apply to the large US, Swiss and Japanese banks. Other hypotheses will be kept on the PRA's watch. For EEA branches, additional scrutiny is planned if they may impact financial stability in the $\mathrm{UK}^{139}$. Overseas mutual societies with branches in the UK would not be materially affected. A similar approach has been proposed by the Bank of England with respect to insurers, $\mathrm{CCPs}^{140}$ and CSDs.

In its most recent statement ${ }^{141}$ the PRA has essentially confirmed its previous policies with respect to the authorisation and supervision of branches of international banks ${ }^{142}$, which would be applicable to banks from the EU. This policy would apply to all non-UK headquartered groups, both already present or establishing themselves in the future. The basic rule is that these banks could establish themselves as branches, unless incorporation would apply in order to protect local depositors. Systemic wholesale branches are allowed under the condition that the PRA has sufficient assurance over the supervisibility of the branch. Consistency with the UK regulatory framework would be based on an equivalence assessment. It is not expected that the non-EEA international banks operating in the UK would be affected. If that is not the case, it would require the bank to incorporate as a subsidiary. Retail ${ }^{143}$, and hence significant deposit taking businesses, will not qualify for the branch regime and would have to incorporate in the UK as a separate subsidiary, as these might endanger the UK depositors and constitute a danger to the UK financial system and its deposit protection scheme (risks exceeding $\left.500 \mathrm{~m} \mathrm{GBP}{ }^{144}\right)^{145}$. Banks which do not exceed these criteria can continue to function as branches, depending on elements such as their systemic nature, their interconnectedness with the UK

139 PRA, Consultation Paper CP29/17, pp. 29-30 (Box 6).

$140 \mathrm{BoE}$, The Bank of England's approach to the authorisation and supervision of international banks, insurers and central counterparties (December 20, 2017).

141 PRA, Policy Statement PS 3/18, p.

142 See PRA, Policy Statement PS 3/18.

1435000 retail and SME customers.

144 Under the Financial Services Compensation Scheme.

145 See the letter from S. Woods, Contingency planning for the UK's withdrawal from the European Union (April 7, 2017); this policy was inaugurated by the BOE in 2015, taking also into account the resolution system in its home jurisdictions: M. Arnold, ING chief warns over UK access for European banks after Brexit, Financial Times (August 2, 2017). 
financial system and the degree of supervisory cooperation and regulatory equivalence. They could act worldwide.

The FCA regulates the conduct for a very wide range of financial services firms, including banks and investment firms. It also acts as the prudential regulator for a significant segment of these firms ${ }^{146}$ and shares its authority with the PRA for banks. Its strategic objectives include the protection of the consumers of financial services, protect financial markets and promote competition in and among markets. In the Brexit context, the continuity of the services and the avoidance of disruption are central concern $s^{147}$. To that effect, the FCA mentioned that during the implementation period, in its view the EU passport should remain applicable to UK firms ${ }^{148}$. The FCA could issue temporary permissions to firms exclusively active in the UK and this to ensure continuity while not excluding new activity to be developed ${ }^{149}$. In its external communication, the FCA drew attention to some specific issues that may disrupt this continuity ${ }^{150}$ : one concerns the continuity of the contracts, now generally based on a reference to UK law ${ }^{151}$. The application of other legal systems, e.g. in the insurance field, might be very disruptive, while the concern was expressed that

14656000 firms are subject to the FCAs general oversight and 18000 firms to its prudential supervision.

147 FCA, Statement on UK withdrawal (December 20, 2017), available at https://www. fca.org.uk/news/statements/fca-statement-eu-withdrawal.

148 See FCA, Statement on UK withdrawal (December 20, 2017). As a consequence, EU law would remain applicable. See for an update: FCA, Preparing your firm for Brexit, (October 18, 2018), available at https://www.fca.org.uk/firms/preparing-for-brexit; N. Delfas, Maintaining market confidence: an update on Brexit (November 5, 2018), available at https://www.fca.org.uk/news/speeches/maintaining-market-confidenceupdate-brexit.

149 FCA, Consultation Paper CP18/29, Temporary permissions regime for inbound firms and funds (October 10, 2018). Available at https://www.fca.org.uk/publications/consultation-papers/cp18-29-temporary-permissions-regime-inbound-firms-and-funds. The EU technical standards will also be maintained.

150 See the statement made by A. Bailey on contract continuity, FCA's Bailey Says Solve Contract Continuity in Brexit, Bloomberg Markets (December 1, 2017), available at htt ps://www.bloomberg.com/news/videos/2017-12-01/fca-s-bailey-solve-contract-conti nuity-in-brexit-video.

151 Letter from S. Woods, Firms'preparations for the UK's withdrawal from the European Union: planning assumptions (December 20, 2017), available at https://www.bankofengland.co.uk/-/media/boe/files/prudential-regulation/letter/2017/firms-preparations-for-uk-withdrawal-from-the-eu.The treasury announced that it will legislate for UK and non-UK contracts. Especially insurance contracts call attention. See on this topic in the field of derivatives ISDA, Response of ISDA to the European Commission Consultation Document on conflict of laws rules for third party effects of transactions in securities and claims (June 29, 2017). The future ISDA agreement will refer to UK, Irish and US law. 
this might even endanger the investors protection schemes ${ }^{152}$. Another point addressed to the position of the asset managers after Brexit, and especially the delegation practice, largely a reaction to the ESMA Opinion on the same subject where the "letter-box" entities have been severely criticised. The FCA declared that appropriate oversight is exercised on this practice, but that it is conscious that sensible outcomes have to be found on this subject ${ }^{153}$. Close cooperation is needed with the EEA regulators and the ESAs.

The powers of the FCA will also be extended including supervision of Credit ratings agencies and trade repositories, as these are now supervised by ESMA $^{154}$.

\section{Conclusion}

After the United Kingdom will have left the European Union, the question will arise what the rules are for further activities in each other's financial markets. Brexit will not be the end of financial services being provided in each other jurisdictions. Even in case of a hard Brexit, activities will be carried on through separate legal entities or even branches. But the rules will change and the United Kingdom will have the status of a third country, losing its rights based on the "passport". Many of the issues mentioned in this paper could however be solved by a transition agreement, even in absence of a full passport as applicable pre-Brexit. At the moment of writing, there is no definite information available which way such an agreement - if any - might go. A transition period may extent until 2020, during which existing rules would remain in force, but afterwards, we do not know.

The comparative analysis of the policy positions on the background of the applicable regulations reveals some interesting differences.

For both parties, there is a clear intention to defend or promote the attractiveness of their own market. The way this objective is achieved is however considerably different.

For the EU, the master card is the passported access to the EU, the large European economic zone, allowing to offer services without additional authorisations in all EU member States. Only firms legally established in EU

152 C. Binham, FCA raises concerns over pots-Brexit access to consumer protections, Financial Times (October 10, 2017).

153 C. Binham, FCA warns against post-Brexit shake-up of investment rules, Financial Times (September 28, 2017).

154 See FCA, Statement on UK withdrawal (December 20, 2017). 
Member States are entitled to the benefits of the passport. Whether third country firms could also qualify for the passport, depends on their form of establishment; with respect to certain activities, access to EU markets can be obtained, provided that the firm has fully conformed to EU rules, that compliance is ensured and can be verified by EU bodies - such as the ESAs or their members - and that where needed these rules can be applied by the courts, ultimately under the guidance of the European Court of Justice. The outcome of this approach is that the business will have to be run out of a local legal entity, a subsidiary, triggering quite substantial regulatory requirements. If the branch form is chosen, access will be limited to the state of location and subject to that state's authorisation after having met some high-level conditions, however, without local EU supervision. Over time third country investment firms may obtain an EU-wide passport, but only after the EU Commission has declared their legal and regulatory regime equivalent. Access to the EU will become more difficult, more expensive, but not impossible.

The UK repeatedly points to the importance of London as the international financial centre, especially for services that are not on offer in most other EU jurisdictions, or at least not on the same terms (e.g. CCPs, wholesale banking, asset management). Therefore, the expectation is that financial institutions will keep their actual presence in London or may even open a new one, and this to service the EU, but also the world financial markets. To support this tendency, the UK regulations continues to offer wide access by way of branches, not only for the large international wholesale banks, but also for smaller institutions provided the supervisory regime is equivalent or at least acceptable to the UK authorities. When UK investors could be endangered, a stricter regime will apply, including mandatory incorporation as a separate subsidiary.

The way the attractiveness of each of these two markets is being presented points to a difference in approach: welcoming to foreign entrants in the UK, caution and defensiveness in the EU.

The EU side has reached out to firms located in the UK to relocate to the EU. The relocation as such is a quite complex exercise and would normally imply creation or reactivation of subsidiaries. Relocation will be quite expensive for new entrants.

Is this a remnant of "Fortress Europe"? For many years, the EU has protected its markets against foreign operators, rarely excluding full access, but often making access available only under strict conditions, spelled out in countless regulations These restrictions are not always attributable to measures of economic policy being based on objectives as investor protection, market efficiency, a level playing field or financial stability. In many cases, they may also result in protecting the EU financial industry, not necessarily making it more resilient. 
The UK approach is different: in its quite accommodating view on the financial services industry, it has been able to attract all mayor players in the world, offering the most sophisticated services in terms of market organisation, transactional expertise and financing power, but also in dispute settlement.

Between the two systems, bridges will have to be built. These come in different shapes: as there is no clarity on the shape the Brexit transition regime, one can hope that the market forces will drive the regulatory systems towards identical, or at least parallel solutions. The internal financial services market could be maintained, provided the supervisors agree on common approaches. A lesser solution would be the recognition of equivalence, a less stable, partial solution, but flexible and adaptable to new market needs $s^{155}$. Unilateral measures abound, UK firms get full access to the EU if they establish a subsidiary there. If they are less ambitious, a branch may do as well. Access rights can be granted by equivalence decisions.

What will be the effect of these changes on the relocation of financial institutions or of financial activity in one jurisdiction or the other is difficult to measure. A certain number of large banking groups have indicated that they relocate part of their activities to existing or new subsidiaries in Frankfurt, Dublin, Paris or Amsterdam, affecting some - initially limited - part of their staff to the new location. The same applies to the relocation of parts of trading platforms. The proximity to EBA may also play some role. In the other direction, about 1200 UK entities are branches of EU firms and many of these will have to be authorised by the PRA. It is not possible to predict what the effect on financial activity and employment will be. Moreover, much will depend on the long-term effect on the development of the business in both markets.

155 E. Wymeersch, Third-Country Equivalence and Access to the EU Financial Markets Including in Case of Brexit, J. Fin. Reg. 2018, 209. 